\title{
Biomarker roles identification of miR-106 family for predicting the risk and poor survival of colorectal cancer
}

\author{
Qiliang Peng ${ }^{1,2+}$, Yi Shen $^{3+}$, Peifeng Zhao ${ }^{1,2}$, Ming Cheng ${ }^{4}$, Yaqun Zhu ${ }^{1,2}$ and Bo Xu ${ }^{4^{*}}$
}

\begin{abstract}
Background: Recent studies have extensively investigated the roles of miR-106 in colorectal cancer (CRC). However, the associations and molecular mechanism underlying the roles of miR-106 in CRC remain unclear. We aimed to thoroughly investigate the biomarker roles of miR-106 for predicting the risk and survival outcome in CRC.

Methods: We first conducted a comprehensive meta-analysis to quantitatively evaluate the roles of miR-106 in the diagnosis and prognosis of CRC. Then, we qualitatively explored the biomarker roles of miR-106 in CRC through an integrative bioinformatics analysis.

Results: The results indicated that miR-106 yielded a combined AUC of 0.79 (95\% Cl: 0.76-0.83), with a pooled sensitivity of 0.50 ( $95 \%$ Cl: $0.32-0.68$ ) and a pooled specificity of 0.93 ( $95 \% \mathrm{Cl}: 0.79-0.98$ ) for discriminating CRC cases from normal controls. Moreover, patients with higher expression of miR-106 were significantly associated with shorter disease-free survival (HR: 1.73; 95\%Cl: 1.23-2.44) and overall survival (HR: 1.39; 95\%Cl: 1.09-1.77). Finally, gene ontology and pathway analysis demonstrated that miR-106 family was highly involved in the initiation and progression of CRC and indicated the potential molecular mechanism for miR-106 in CRC.

Conclusions: Our results indicated that miR-106 showed promising potential as diagnostic and prognostic biomarker for CRC. Nevertheless, the underlying molecular mechanism of miR-106 family involved in CRC requires further investigation.
\end{abstract}

Keywords: Colorectal cancer, Biomarker, Meta-analysis, Bioinformatics

\section{Background}

Colorectal cancer (CRC) remains as one of most prevalent malignancies in both developed and developing countries, and it has become a global public health concern due to high mortality [1]. As early symptoms of CRC patients are not typical, most of the CRC cases occur in locally advanced stages when the overall 5-year survival rate are very low. Although a series of predictive methods for diagnosis and prognosis of CRC are

\footnotetext{
*Correspondence: sdfeyxubo@163.com

${ }^{\dagger}$ Qiliang Peng and Yi Shen contributed equally to this work.

${ }^{4}$ Dept. of General Surgery, The Second Affiliated Hospital of Soochow University, San Xiang Road No. 1055, Suzhou 215004, Jiangsu, China Full list of author information is available at the end of the article
}

available, their clinically application values are limited due to high costs, lack of sensitivity or inconvenience [2]. Thus, new, invasive and more specific methods for early detection and survival prediction are necessary to improve the survival status for CRC patients [3].

MicroRNAs (miRNAs) are a group of small noncoding RNA molecules, which play fundamental roles in regulating gene expression through inhibiting mRNA translation or inducing degradation of the mRNA, and then participate in a wide variety of key physiological processes including cell growth, differentiation, invasion and metastasis [4]. In recent years, numerous studies have suggested that miRNAs may provide a new idea as

(c) The Author(s). 2020 Open Access This article is licensed under a Creative Commons Attribution 4.0 International License, which permits use, sharing, adaptation, distribution and reproduction in any medium or format, as long as you give appropriate credit to the original author(s) and the source, provide a link to the Creative Commons licence, and indicate if changes were made. The images or other third party material in this article are included in the article's Creative Commons licence, unless indicated otherwise in a credit line to the material. If material is not included in the article's Creative Commons licence and your intended use is not permitted by statutory regulation or exceeds the permitted use, you will need to obtain permission directly from the copyright holder. To view a copy of this licence, visit http://creativecommons.org/licenses/by/4.0/ The Creative Commons Public Domain Dedication waiver (http://creativecommons.org/publicdomain/zero/1.0/) applies to the data made available in this article, unless otherwise stated in a credit line to the data. 
biomarkers for tumor diagnosis, prognosis and prediction of efficacy [5]. As one of the most common studied miRNA biomarkers, miR-106 has gained great attention as a novel biomarker in cancer detection and survival prediction [6]. Several studies have previously indicated that miR-106 could be specifically used as a promising diagnostic marker for distinguishing CRC patients from normal subjects [7]. Moreover, miR-106 expression level seems to be correlated with CRC patient survival [8]. Nevertheless, different confounding factors, such as sample sources, sample sizes, detection methods, may result in inconsistent and conflicting conclusions. Moreover, the pathological mechanisms of miR-106 involved in CRC are still not fully understood.

Therefore, this study aimed to quantitatively determine the potential biomarker value of miR-106 family and provide a more comprehensive and reliable conclusion on the relationship between miR-106 expression and the diagnosis and prognosis of CRC; in addition, an integrated bioinformatics was performed for uncovering the biomarker functions of miR-106 family at the systems biology level.

\section{Methods}

\section{Search strategy}

Relevant studies published before May 20, 2019 were screened through a search in PubMed, EMBASE, Web of Science, and Cochrane Library databases using the following terms: ("colorectal" or "rectal" or "rectum" or "colon" or "CRC") and ("cancer", "carcinoma", "tumor", "neoplasm") and ("microRNA-106" or "miRNA-106" or "miR-106" or "miRNA106"). In addition, we manually examined the references from retrieved articles, including all of the identified studies, reviews, and editorials.

\section{Inclusion and exclusion criteria for study selection}

For inclusion, studies had to meet the following criteria: (1) Investigated the diagnostic or prognostic value of miR-106 family in CRC; (2) Diagnosed of CRC with gold standard; (3) Provided the data to calculate the true positives (TP), false positives (FP), false negatives (FN), true negatives (TN) for diagnosis or HRs and 95\% confidence intervals (CIs) for prognosis. For the exclusion, studies were excluded if they: (1) Had nothing to do with our topic; (2) Published as reviews, meta-analysis, letters, or case reports; (3) Provided incomplete data; (4) Were non-English publications.

\section{Data extraction}

Study characteristics and original data were collected independently by two authors from qualified studies, including (1) basic characteristics of the studies including first author, publication year, patient ethnicity, patient age, sample sizes, sample sources, detection method of
miR-106 family; (2) diagnostic parameters of miR-106 family, including sensitivity, specificity, and AUC; (3) prognostic parameters of miR-106 family, including follow-up time, the survival outcomes (disease-free survival, DFS; overall survival, OS), HRs and 95\% CIs. If HRs and $95 \%$ CIs were not reported in the identified articles, they were estimated from Kaplan-Meier curves with methods described by Tierney et al.

\section{Quality assessment}

Two independent investigators evaluated the quality of individual studies respectively based on the QUADAS-2 tool (Quality Assessment of Diagnostic Accuracy Studies 2) for the diagnostic records and the NOS (NewcastleOttawa Scale) tool for the prognostic studies $[9,10]$.

\section{Statistical methods}

For the diagnostic meta-analyses, we evaluated the overall diagnostic results by applying the TP, FP, FN, and TN test results extracted directly from each study for calculating the pooled values including sensitivity, specificity, the positive likelihood ratio (PLR), the negative likelihood ratio (NLR), the diagnostic odds ratio (DOR) with a bivariate random effect-regression model [11]. Meanwhile, we constructed the summary receiver operator characteristic (SROC) curve and calculated the area under the curve (AUC) for quantify the diagnostic performance of miR106 family [12]. The heterogeneity among studies was examined through the $\mathrm{Q}$ test and the $\mathrm{I}^{2}$ value. The $P$-value $<0.05$ for the $Q$ test or $\mathrm{I}^{2} \geq 50 \%$ indicated that there was obvious heterogeneity among the selected studies [13]. We applied sensitivity analyses for identifying the possible sources of the heterogeneity. The Deeks' funnel plot asymmetry test was used to explore the publication bias ( $P$ value $<0.05$ indicated statistically significant).

For the prognostic meta-analyses, HRs and their 95\% CIs extracted from studies were pooled for evaluating the prognostic value of miR-106 in CRC. When heterogeneity across studies existed, the random-effect model was conducted for the meta-analysis; otherwise, the fixed-effect model was applied. Subgroup analysis, metaregression, subgroup and sensitivity analyses were conducted to identify the sources of heterogeneity [14]. In the end, we selected the Begg's and Egger's tests to evaluate the potential publication bias among the included studies [15]. All the statistical analyses were performed using STATA 12.0 software.

\section{Integrated functional enrichment analysis}

The biomarker roles of miR-106 may be primarily explained by its transcriptional targets and the involved signal pathways. Therefore, an integrated functional analysis was performed on the targets of miR-106 family. We firstly collected the presumptive targets of miR-106 


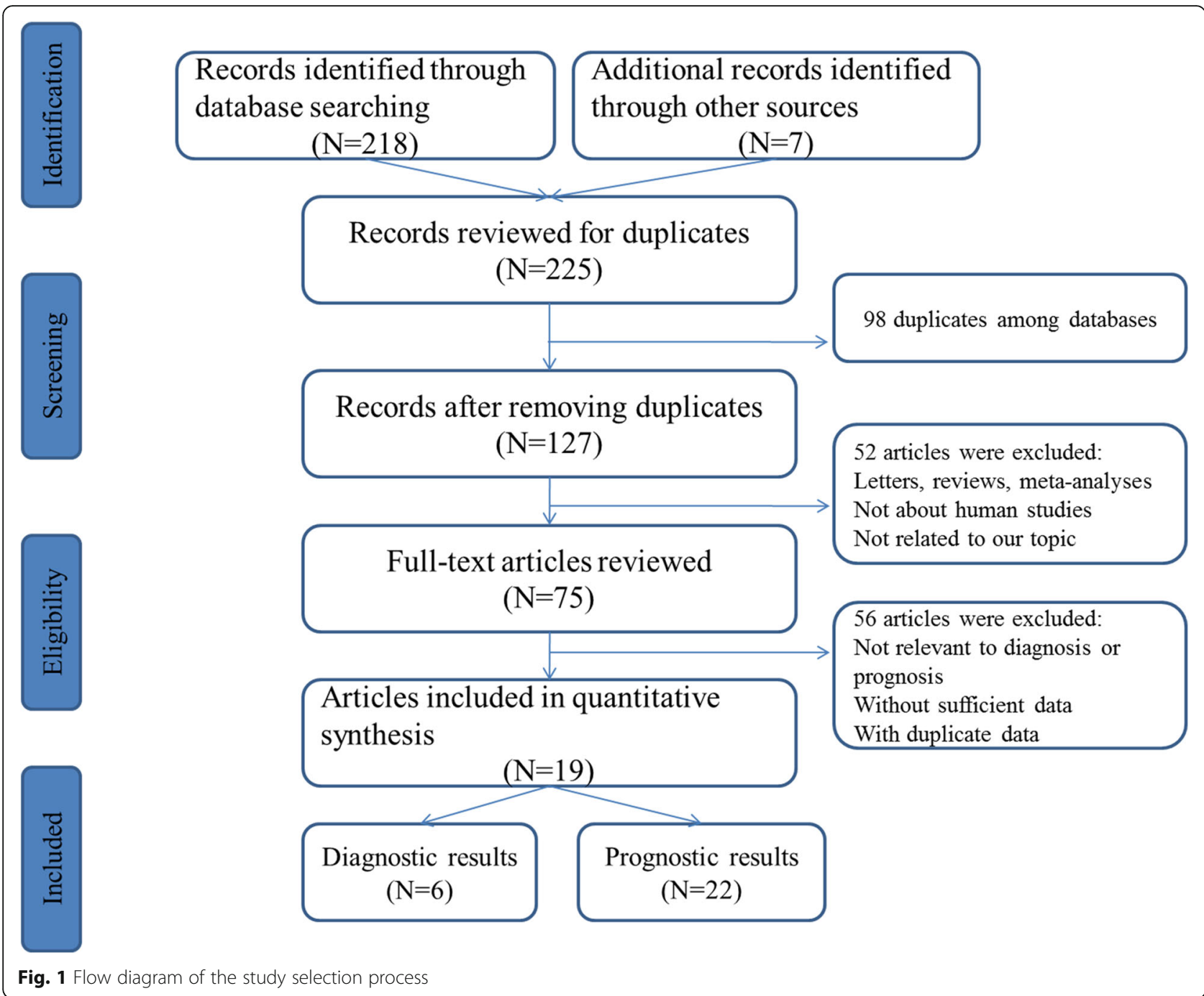

family from TarBase (v8.0), which is a powerful database of experimentally supported miRNA targets [16]. For targets function annotation, the gene ontology (GO) analysis was analyzed at three different levels: biological processes (BP), cell component (CC) and molecular function (MF) [17]. For pathway enrichment, the predicted targets of miR-106 family were mapped applying the Kyoto Gene and Genome Encyclopedia (KEGG) database [18]. In the present study, the GO and KEGG pathway enrichment analysis were accomplished by online analysis of the Database for Annotation, Visualization and Integrated Discovery (DAVID) tool [19]. Significant enrichment terms were considered as $P$-value $<0.05$.

Table 1 The main features of the included studies for miR-106 family in the diagnosis of CRC

\begin{tabular}{|c|c|c|c|c|c|c|c|c|c|c|c|c|c|c|c|c|c|}
\hline \multirow[t]{2}{*}{ First author } & \multirow[t]{2}{*}{ Year } & \multirow[t]{2}{*}{ Country } & \multirow[t]{2}{*}{ Ethnicity } & \multicolumn{3}{|l|}{ Case } & \multicolumn{5}{|c|}{ Control } & \multirow{2}{*}{$\begin{array}{l}\text { Sample } \\
\text { source }\end{array}$} & \multirow[t]{2}{*}{ Methods } & \multirow[t]{2}{*}{ miRNA } & \multirow[t]{2}{*}{ AUC } & \multirow[t]{2}{*}{ Sensitivity } & \multirow[t]{2}{*}{ Specificity } \\
\hline & & & & M & $\mathrm{F}$ & $\mathrm{N}$ & Age & $M$ & $\mathrm{~F}$ & $\mathrm{~N}$ & Age & & & & & & \\
\hline ] & 2 & J & Asian & NA & NA & 138 & $\Lambda$ & NA & NA & 126 & $N$ & & & a & 26 & & $\%$ \\
\hline 10 & 2013 & Germ & Europ & 45 & 35 & 80 & 68 & 60 & 84 & 144 & 62 & Plasma & PCR & 06b & 0.565 & $19.00^{\circ}$ & $5.00 \%$ \\
\hline [20] & 2013 & Japan & Asian & 69 & 48 & 117 & 65 & 66 & 41 & 107 & 60 & Feces & RT-PCR & $-106 a$ & N & 34.20 & $7.20 \%$ \\
\hline Chen et al. [22] & 16 & 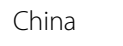 & Asian & 60 & 40 & 100 & 60 & 44 & 35 & 79 & 60 & Plasma & (0 & $\mathrm{sa}$ & 0.605 & $74.00 \%$ & 44400 \\
\hline et & 2015 & China & Asian & 113 & 62 & 175 & 57 & 51 & 79 & 130 & 54 & Se & RT-PCR & miR-106a & 0.813 & $69.00 \%$ & $83.00 \%$ \\
\hline le et al. [24] & 2017 & China & Asian & 23 & 19 & 42 & 63 & 24 & 18 & 42 & 60 & Plasma & RT-PCR & miR-106a & 0.858 & $74.20 \%$ & $86.10 \%$ \\
\hline
\end{tabular}




\section{Results}

Literature search and demographic characteristics As shown in Fig. 1, on the basis of initial literature research, a total of 225 qualified articles were involved from the selected databases. According to the inclusion and exclusion criteria, after removing the duplicates and reviewing the texts, 19 articles including 28 studies were utilized for the final analysis, of which 6 studies were about the value of miR-106 family for CRC diagnosis and 22 studies were about CRC prognosis [8, 20-36]. All studies applied quantitative reverse transcription PCR (qRT-PCR) to measure the expression of miR-106 family. The main characteristics of each study were summarized in Table 1 and Table 2. The scores suggested that the majority of enrolled studies had moderately good quality.

\section{Diagnostic value of miR-106 family in CRC}

A total of six studies containing 652 patients and 628 normal controls assessed the diagnostic value of miR106 family for CRC. As shown in Fig. 2, $\mathrm{I}^{2}$ values for sensitivity and specificity were $96.48 \%$ (95\% CI: $94.81-$ 98.15\%; $P<0.001)$ and 91.33\% (95\% CI: 85.86-96.70\%; $P<0.001)$ respectively, indicating significant

Table 2 The main features of the included studies for miR-106 family in the prognosis of CRC

\begin{tabular}{|c|c|c|c|c|c|c|c|c|c|c|c|c|c|}
\hline First author & Year & Country & Ethnicity & $\mathrm{M} / \mathrm{F}$ & $N$ & Age & $\begin{array}{l}\text { TNM } \\
\text { stage }\end{array}$ & $\begin{array}{l}\text { Sample } \\
\text { source }\end{array}$ & miRNA & Methods & Endpoints & $\begin{array}{l}\text { Follow-up } \\
\text { time } \\
\text { (months) }\end{array}$ & Hazard ratio \\
\hline Diaz et al. [25] & 2008 & Spain & European & $71 / 39$ & 110 & 69 & I-IV & Tissue & miR-106a & RT-PCR & DFS & 68 & $0.36(0.17-0.77)$ \\
\hline $\begin{array}{l}\text { Zhang } \\
\text { et al. [28] }\end{array}$ & 2013 & China & Asian & $79 / 59$ & 138 & 65 & $\|$ & Tissue & $\begin{array}{l}\text { miR- } \\
106 b\end{array}$ & RT-PCR & DFS & 60 & $2.36(0.93-6.03)$ \\
\hline $\begin{array}{l}\text { Zhang } \\
\text { et al. [28] }\end{array}$ & 2013 & China & Asian & $86 / 51$ & 137 & 65 & I-IV & Tissue & $\begin{array}{l}\text { miR- } \\
106 b\end{array}$ & RT-PCR & DFS & 60 & $2.15(0.90-5.11)$ \\
\hline $\begin{array}{l}\text { Zhang } \\
\text { et al. [28] }\end{array}$ & 2013 & China & Asian & $\begin{array}{l}266 / \\
194\end{array}$ & 460 & 65 & I-IV & Tissue & $\begin{array}{l}\text { miR- } \\
106 b\end{array}$ & RT-PCR & DFS & 60 & $2.03(1.34-3.06)$ \\
\hline $\begin{array}{l}\text { Kjersem } \\
\text { et al. [29] }\end{array}$ & 2014 & Norway & European & $82 / 68$ & 150 & 61 & $|-|||$ & Plasma & miR-106a & RT-PCR & DFS & NA & $1.13(0.90-1.41)$ \\
\hline $\begin{array}{l}\text { Bullock } \\
\text { et al. [31] }\end{array}$ & 2015 & UK & European & $38 / 12$ & 50 & 74 & $|-|||$ & Tissue & miR-106a & RT-PCR & DFS & 96 & $2.91(1.32-6.42)$ \\
\hline Li et al. [23] & 2015 & China & Asian & $113 / 62$ & 175 & 57 & $\|-\| \|$ & Serum & miR-106a & RT-PCR & DFS & 36 & $3.02(1.36-6.73)$ \\
\hline $\begin{array}{l}\text { Zhang } \\
\text { et al. [34] }\end{array}$ & 2015 & China & Asian & $54 / 39$ & 93 & 60 & $|-|||$ & Tissue & $\begin{array}{l}\text { miR- } \\
106 b\end{array}$ & RT-PCR & DFS & 61 & $\begin{array}{l}3.47(1.13- \\
10.63)\end{array}$ \\
\hline Yue et al. [33] & 2015 & China & Asian & $42 / 28$ & 70 & 65 & I-IV & Tissue & miR-106a & RT-PCR & DFS & 80 & $2.21(1.46-4.11)$ \\
\hline $\begin{array}{l}\text { Caritg } \\
\text { et al. [35] }\end{array}$ & 2016 & Spain & European & $43 / 26$ & 69 & 67 & $\|$ & Tissue & $\begin{array}{l}\text { miR- } \\
106 b\end{array}$ & RT-PCR & DFS & 140 & $2.25(0.88-5.75)$ \\
\hline $\begin{array}{l}\text { Hao et al. } \\
{[8,36]}\end{array}$ & 2017 & China & Asian & $92 / 46$ & 138 & 56 & I-IV & Tissue & miR-106a & RT-PCR & DFS & 60 & $1.22(0.70-2.12)$ \\
\hline Diaz et al. [25] & 2008 & Spain & European & $71 / 39$ & 110 & 69 & I-IV & Tissue & miR-106a & RT-PCR & OS & 68 & $0.53(0.26-1.07)$ \\
\hline $\begin{array}{l}\text { Schetter } \\
\text { et al. [26] }\end{array}$ & 2008 & USA & Caucasians & $66 / 18$ & 84 & 65 & I-IV & Tissue & miR-106a & RT-PCR & OS & 68 & $2.40(1.20-5.10)$ \\
\hline $\begin{array}{l}\text { Bovell et al. } \\
\text { [27] }\end{array}$ & 2013 & UK & European & $\begin{array}{l}188 / \\
193\end{array}$ & 381 & 65 & I-IV & Tissue & miR-106a & RT-PCR & OS & 180 & $1.42(1.01-2.01)$ \\
\hline $\begin{array}{l}\text { Kjersem } \\
\text { et al. [29] }\end{array}$ & 2014 & Norway & European & $82 / 68$ & 150 & 61 & $|-|||$ & Plasma & miR-106a & RT-PCR & OS & NA & $1.17(0.90-1.52)$ \\
\hline Ak et al. [30] & 2014 & Turkey & European & $23 / 17$ & 40 & 37 & I-IV & Tissue & miR-106a & RT-PCR & OS & 24 & $1.46(0.40-5.37)$ \\
\hline $\begin{array}{l}\text { Bullock } \\
\text { et al. [31] }\end{array}$ & 2015 & UK & European & $38 / 12$ & 50 & 74 & $|-| \mid$ & Tissue & miR-106a & RT-PCR & OS & 96 & $2.25(1.00-5.04)$ \\
\hline $\begin{array}{l}\text { Wang et al. } \\
{[32]}\end{array}$ & 2015 & China & Asian & $94 / 89$ & 183 & 65 & I-IV & Tissue & $\begin{array}{l}\text { miR- } \\
106 b\end{array}$ & $\mathrm{ISH}$ & OS & 80 & $0.83(0.64-1.07)$ \\
\hline Yue et al. [33] & 2015 & China & Asian & $42 / 28$ & 70 & 65 & I-IV & Tissue & miR-106a & RT-PCR & OS & 80 & $2.07(1.22-3.85)$ \\
\hline $\begin{array}{l}\text { Zhang } \\
\text { et al. [34] }\end{array}$ & 2015 & China & Asian & $54 / 39$ & 93 & 60 & $|-|||$ & Tissue & $\begin{array}{l}\text { miR- } \\
106 b\end{array}$ & RT-PCR & OS & 61 & $\begin{array}{l}3.95(1.05- \\
14.80)\end{array}$ \\
\hline Hao et al. [8] & 2016 & China & Asian & $40 / 25$ & 65 & 60 & I-IV & Tissue & miR-106a & RT-PCR & OS & 60 & $1.40(1.25-1.93)$ \\
\hline Hao et al. [36] & 2017 & China & Asian & $92 / 46$ & 138 & 56 & I-IV & Tissue & miR-106a & RT-PCR & OS & 60 & $1.87(1.13-3.09)$ \\
\hline
\end{tabular}




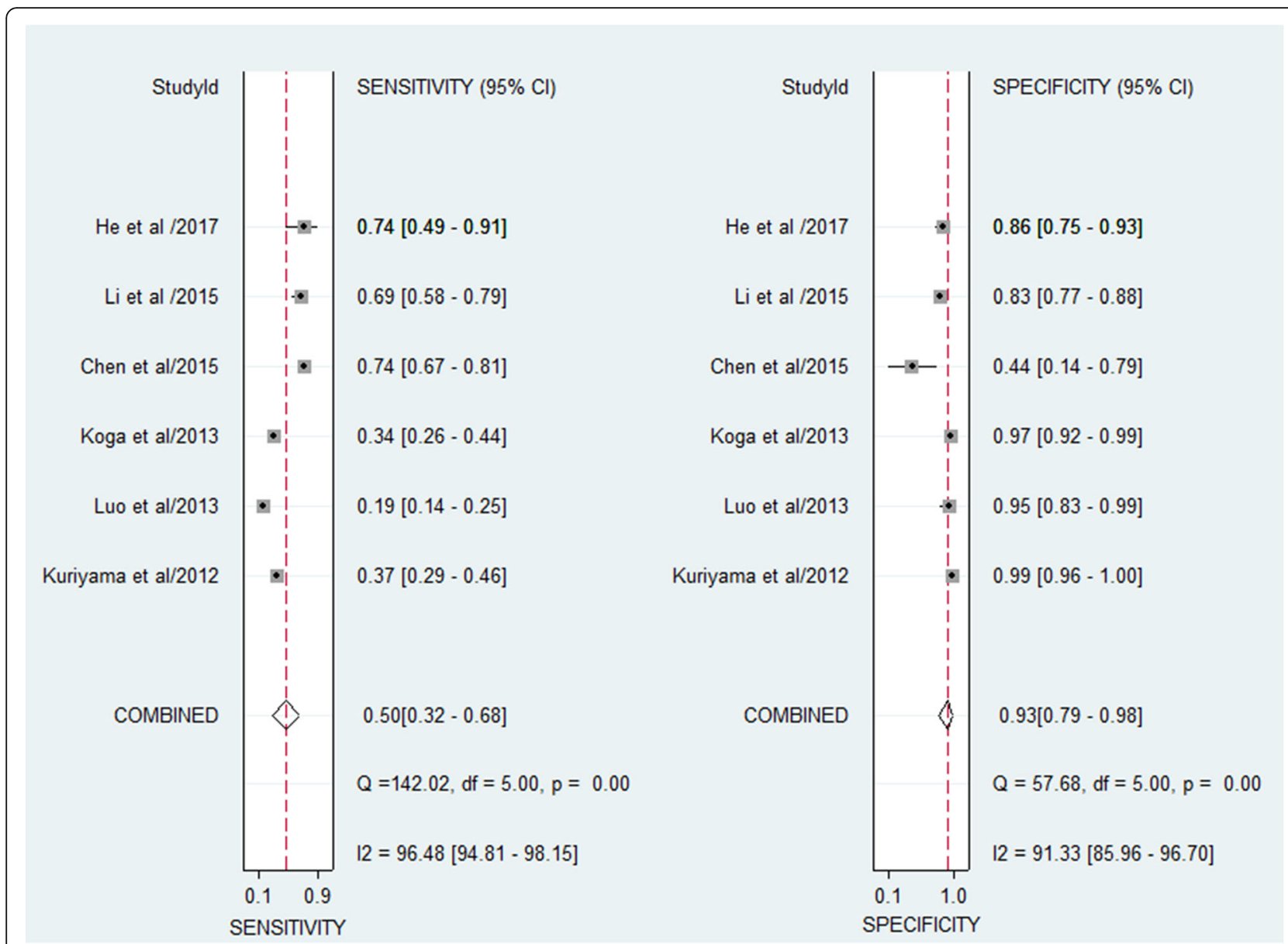

Fig. 2 Forest plots of sensitivities and specificities from test accuracy studies in the diagnosis of CRC

heterogeneity. The pooled sensitivity, specificity, PLR, NLR, and DOR were 0.50 (95\% CI: 0.32-0.68), 0.93 (95\% CI: $0.79-0.98), 7.1$ (95\% CI: $3.0-16.9), 0.54$ (95\% CI: $0.40-0.74$ ), and 13 (95\% CI: 6-28), respectively. The SROC curve analyses indicated a relatively high overall diagnostic accuracy, with AUC values of 0.79 (95\% CI: 0.76-0.83) for miR-106 family in differentiating CRC from healthy controls (Fig. 3).

The goodness of fit and bivariate normality analyses demonstrated that the bivariate meta-analysis model was moderately robust (Fig. 4). Besides that, one outlier study was identified using the method of influence analysis. After omitting it, minimal changes in sensitivity (0.50 vs. 0.56$)$, specificity (0.93 vs. 0.92$)$, PLR (7.1 vs. 6.8), NLR (0.54 vs. 0.48), DOR (13 vs. 14), and AUC (0.79 vs. 0.77$)$ were observed between the overall analysis with and without outlier, suggesting that the study may not have a substantial impact on the combined results. Meta-regression failed to identify the possible source of heterogeneity. Due to the limited number of studies, further analysis about subgroup was not conducted.
Deeks' funnel plot was applied to assess potential publication bias, and the P-value of Deeks' tests was 0.28, suggesting there was no significant publication bias in this analysis.

\section{Prognostic value of miR-106 family in CRC}

A total of 1590 and 1364 patients were enrolled for assessing the prognostic value of miR-106 family in DFS and OS for CRC, respectively. As significant heterogeneity among the enrolled studies was observed (DFS: $\mathrm{I}^{2}=$ $71.0 \%, P<0.001$; OS: $\left.\mathrm{I}^{2}=67.5 \%, P=0.001\right)$, randomeffects models were applied in the analysis for evaluating the prognostic value of miR-106 family in DFS and OS (Fig. 5). According to the pooled analysis, significant associations were identified between miR-106 family and poor DFS (HR $=1.73 ; 95 \%$ CI: $1.23-2.44 ; P=0.002)$ and poor OS (HR $=1.39 ; 95 \%$ CI: $1.09-1.77 ; P=0.008)$.

We performed subgroup analysis to reveal the potential source of the heterogeneity (Table 3 ). In the subgroup of DFS outcomes, we found that the predictive role of miR-106 family was more significant for miR106b $(\mathrm{HR}=2.19 ; 95 \% \mathrm{CI}: 1.61-3.00)$ than miR-106a 


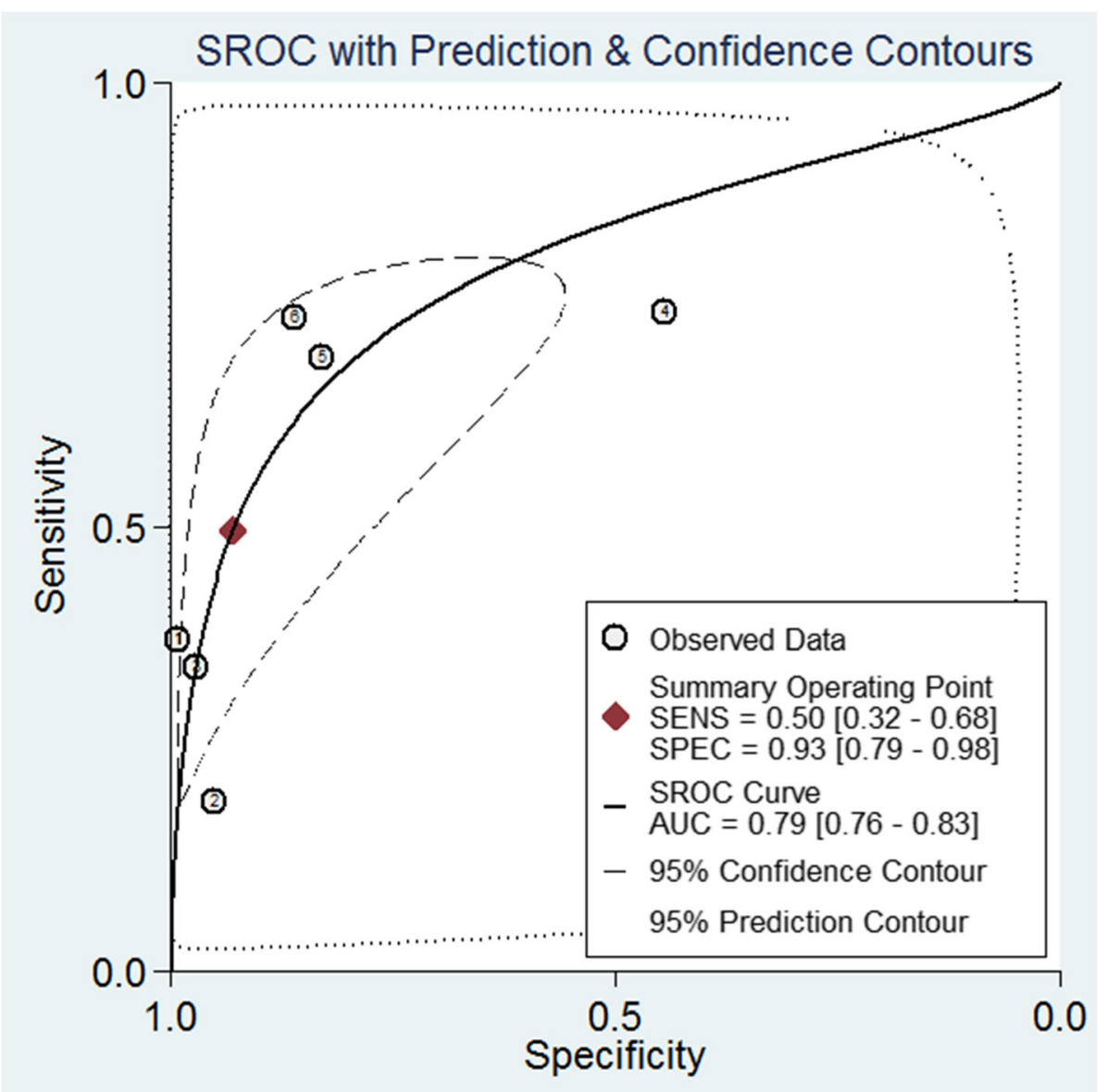

Fig. 3 The SROC curves in the diagnosis of CRC

$(\mathrm{HR}=1.44 ; 95 \% \mathrm{CI}: 0.88-2.35)$. In addition, the association was more significant in Asian patients $(\mathrm{HR}=2.02$; 95\% CI: $1.60-2.57)$ than in European patients ( $\mathrm{HR}=$ $1.24 ; 95 \% \mathrm{CI}: 0.59-2.60)$. In the subgroup of OS outcomes, high miR-106a levels were significantly associated with a worse OS in CRC $(\mathrm{HR}=1.45$; 95\% CI: 1.16-1.80). And for miR-106b, however, this association was not statistically significant $(\mathrm{HR}=1.57$; 95\% CI: $0.35-$ 7.08). When grouped according to the ethnicity, combined HR of Asian patients and non-Asian patients were 1.50 (95\% CI: 1.00-2.24), and 1.33 (95\% CI: 0.94-1.88), respectively, indicating that miR-106 family were more predictive as indicators of poor prognosis in Asian CRC patients.

We also performed meta-regression analysis to investigate the sources of heterogeneity. The meta-regression results revealed that the heterogeneity between studies evaluating miR-106 family in DFS and OS may not be induced by ethnicity $(P>0.05)$, miRNA classification $(P>0.05)$, and sample size $(P>0.05)$.

Sensitivity analysis was further carried out by sequentially omitting individual studies, indicating that there was no obvious influence of individual study on the pooled HRs, no matter which article was removed (Fig. 6).

Finally, potential publication bias was evaluated with Begg's funnel plot and Egger's test (Fig. 7). The $P$-value of 0.15 and 0.21 indicated no significant publication bias exist in the analysis for assessing the association of DFS, OS and miR-106 family expression.

\section{Function exploration of miR-106 family in CRC}

We further performed an integrated bioinformatics analysis to explore the function of miR-106 family and to answer the question why miR-106 family could possess the biomarker characteristics in the diagnosis and prognosis of CRC. Of great importance, we believe that if miR-106 family could play an important role in the occurrence and development of CRC, the genes regulated by miR-106a and miR-106b should also play a part in CRC. We first retrieved the target genes of miR-106a and miR-106b from the powerful TarBase database. Then the gene lists were uploaded to DAVID tool to gain functional enrichment information. 
(a) Goodness-Of-Fit

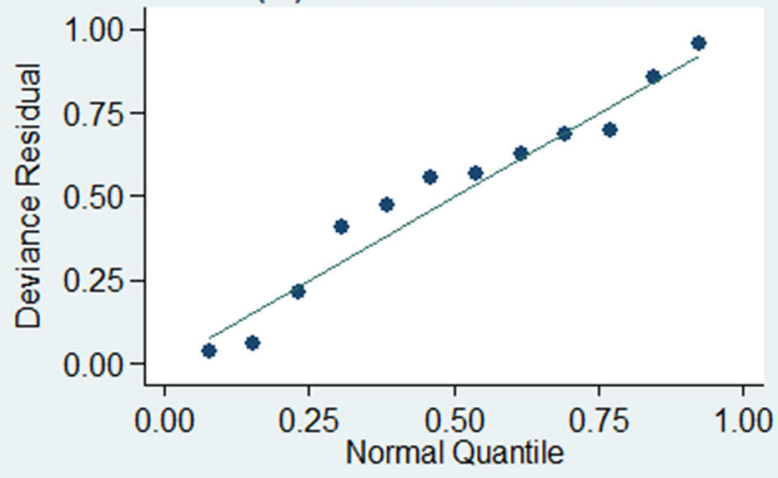

(c) Influence Analysis

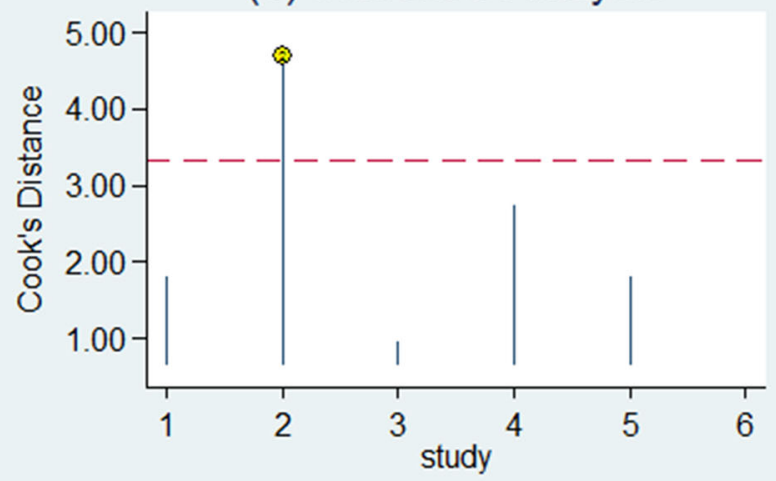

(b) Bivariate Normality

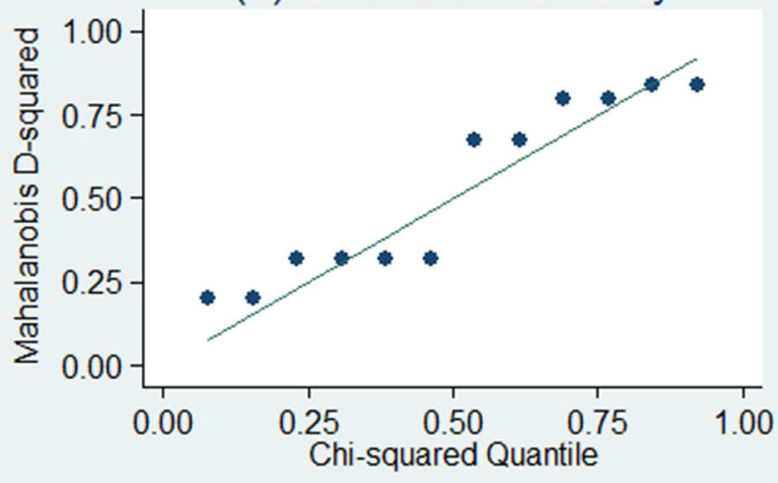

(d) Outlier Detection

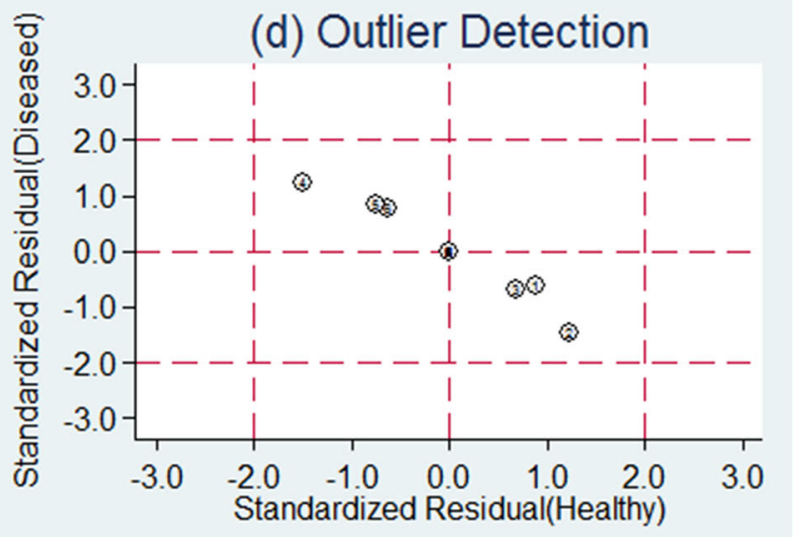

Fig. 4 Sensitivity analysis results in the meta-analysis for diagnosis

In the present study, we mainly concentrated on the top 10 significantly enriched terms for further discussion. The GO enrichment analysis results of miR-106a and miR-106b were presented at Table 4 and Table 5, respectively. The enrichment results given by $\mathrm{GO}$ analysis of miR-106a indicated that the GO terms for BP level associated with the target genes were including phosphorylation, cell cycle arrest, regulation of mitotic cell cycle and transforming growth factor beta (TGF- $\beta$ ) receptor signaling pathway. The associated $\mathrm{CC}$ level for miR-106a included cytoplasm, nucleus, nucleoplasm and nucleolus. The significant GO terms for MF level were closely relevant to binding function and enzyme activity. And for miR-106b, at the BP level, the most significant terms were highly linked with transcription and ubiquitination. At the CC level, the enriched terms were closely relevant to nucleoplasm, nucleus and nucleolus. At the MF level, most enriched terms were also mainly concentrated on binding function and enzyme activity.

The top 10 KEGG pathway enrichment analysis results of miR-106a and miR-106b were listed in Table 6. The enrichment analysis suggested that the targeted genes of
miR-106a were significantly involved in FoxO signaling pathway, focal adhesion, colorectal cancer, pathways in cancer and MAPK signaling pathway. The results of enriched KEGG pathway analysis revealed that the targets of miR-106b were significantly clustered in cell cycle, FoxO signaling pathway, pathways in cancer, RNA degradation and some other diseases including prostate cancer and chronic myeloid leukemia.

\section{Discussion}

Early diagnosis and dynamic monitoring after treatment of CRC is a well-established consensus for patients to receive proper therapeutic treatment and can improve patient survival. Accumulating studies have found miR-106 family as a promising biomarker with key roles in the pathogenesis and tumorigenesis of CRC. Nevertheless, different studies reported with inconsistent results. Thus, by using meta-analysis and bioinformatics analysis, we aimed to obtain a comprehensive understanding of associations between miR-106 expression and diagnosis and prognosis of CRC patients. 


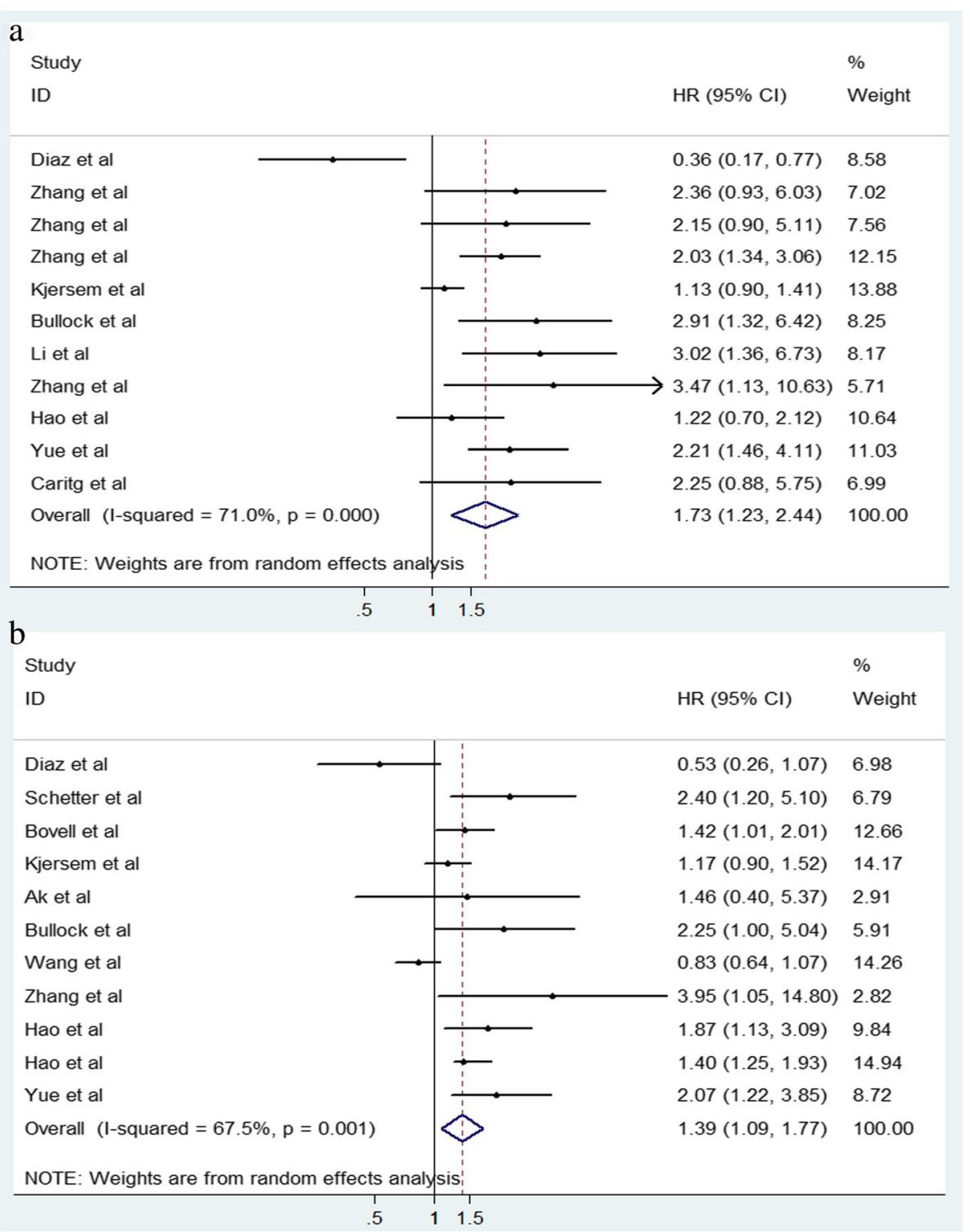

Fig. 5 Forest plots of the correlation between miR-106 family expression level and CRC prognosis. a. Forest plot of DFS; b. Forest plot of OS

It was revealed from the diagnostic meta-analysis that miR-106 family was 50\% sensitive and 93\% specific in distinguishing between CRC and normal controls (AUC: 0.79). The PLR, NLR, and DOR were 7.1, 0.54, and 13, respectively. The overall results suggested that miR-106 family may serve as a promising diagnostic biomarker in the CRC detection with a moderate accuracy. However, there is a long way to go before the application of miR106 family into clinical as they still have insufficient power to accurately detect and diagnose CRC.

Prognostic meta-analysis indicated that patients with high levels of miR-106 family were related to poorer survival than those with low expression levels. The predictive roles were more significant for miR-106a in OS and
miR-106b in DFS. Meanwhile, the results indicated that miR-106 family was more predictive as biomarker of poor prognosis in Asian CRC patients. In all, pooled HR values of DFS and OS correlated with miR-106 expression for CRC patients, which revealed that miR-106 could be an independent risk factor for prognosis and may be used to monitor the therapeutic effects of radical resection or systemic adjuvant therapy.

As miRNAs contribute to tumorigenesis by regulating gene expression in various biological activities, we performed a functional enrichment analysis of the target genes of miR-106 family to explore their potential mechanisms involved in the initiation and progression of CRC. Published literatures revealed that the biological 
Table 3 Results of subgroup and meta-regression analyses in the prognostic meta-analysis

\begin{tabular}{|c|c|c|c|c|c|c|c|}
\hline Outcome & Subgroup & Studies & $\mathrm{HR}(95 \% \mathrm{Cl})$ & $\boldsymbol{P}$-value & Heterogeneity $\left(\mathbf{I}^{\mathbf{2}}\right)$ & $P_{\text {heterogeneity }}$ & Meta-regression ( $\boldsymbol{P}$-value) \\
\hline \multirow[t]{6}{*}{ DFS } & miRNA classification & & & & & & $P=0.237$ \\
\hline & miR-106a & 6 & $1.44(0.88-2.35)$ & $P=0.151$ & $79.9 \%$ & $P<0.001$ & \\
\hline & miR-106b & 5 & $2.19(1.61-3.00)$ & $P<0.001$ & 0 & $P=0.938$ & \\
\hline & Ethnicity & & & & & & $P=0.322$ \\
\hline & Asian & 7 & $2.02(1.60-2.57)$ & $P=0.569$ & $81.7 \%$ & $P=0.001$ & \\
\hline & Non-Asian & 4 & $1.24(0.59-2.60)$ & $P<0.001$ & 0 & $P=0.507$ & \\
\hline \multirow[t]{6}{*}{ OS } & miRNA classification & & & & & & $P=0.584$ \\
\hline & miR-106a & 9 & $1.45(1.16-1.80)$ & $P=0.001$ & $48.6 \%$ & $P=0.049$ & \\
\hline & miR-106b & 2 & $1.57(0.35-7.08)$ & $P=0.555$ & $80.6 \%$ & $P=0.023$ & \\
\hline & Ethnicity & & & & & & $P=0.648$ \\
\hline & Asian & 5 & $1.50(1.00-2.24)$ & $P=0.050$ & $79.1 \%$ & $P=0.001$ & \\
\hline & Non-Asian & 6 & $1.33(0.94-1.88)$ & $P=0.107$ & $56.8 \%$ & $P=0.041$ & \\
\hline
\end{tabular}

processes associated with miR-106 family including phosphorylation, cell cycle and TGF- $\beta$ receptor signaling for miR-106a and transcription, ubiquitination for miR106b, were highly related to the initiation and progression in CRC as they were significantly involved in regulating numerous cellular activities, such as apoptosis, proliferation, differentiation, gene regulation, metabolism, and metastasis [38-41]. Enrichment GO analysis also suggested that miR-106a and miR-106b were both mostly correlated with the vital cell
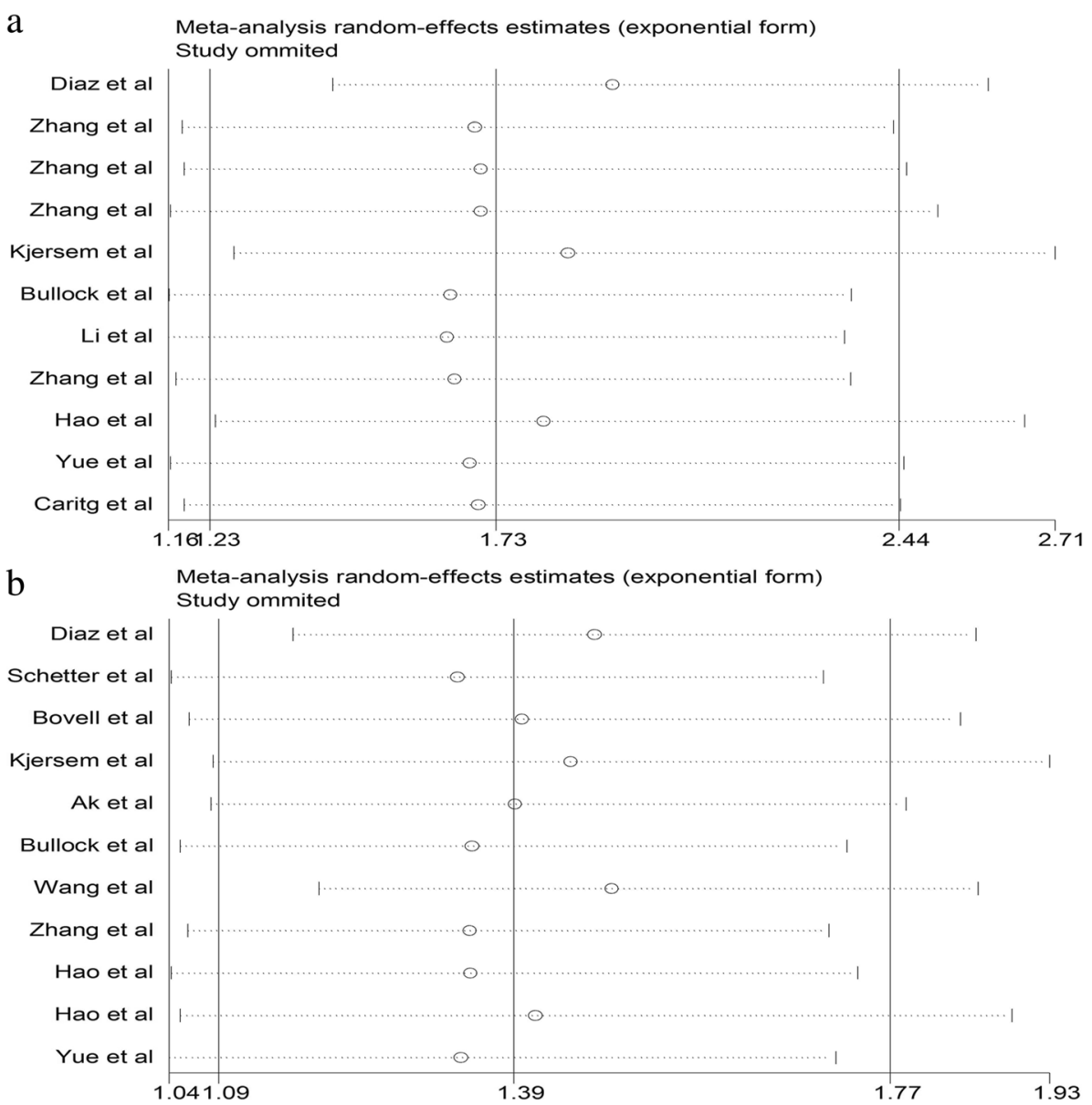

Fig. 6 Sensitivity analyses in the meta-analysis for prognosis. a. Sensitivity analysis for DFS; $\mathbf{b}$. Sensitivity analysis for OS 

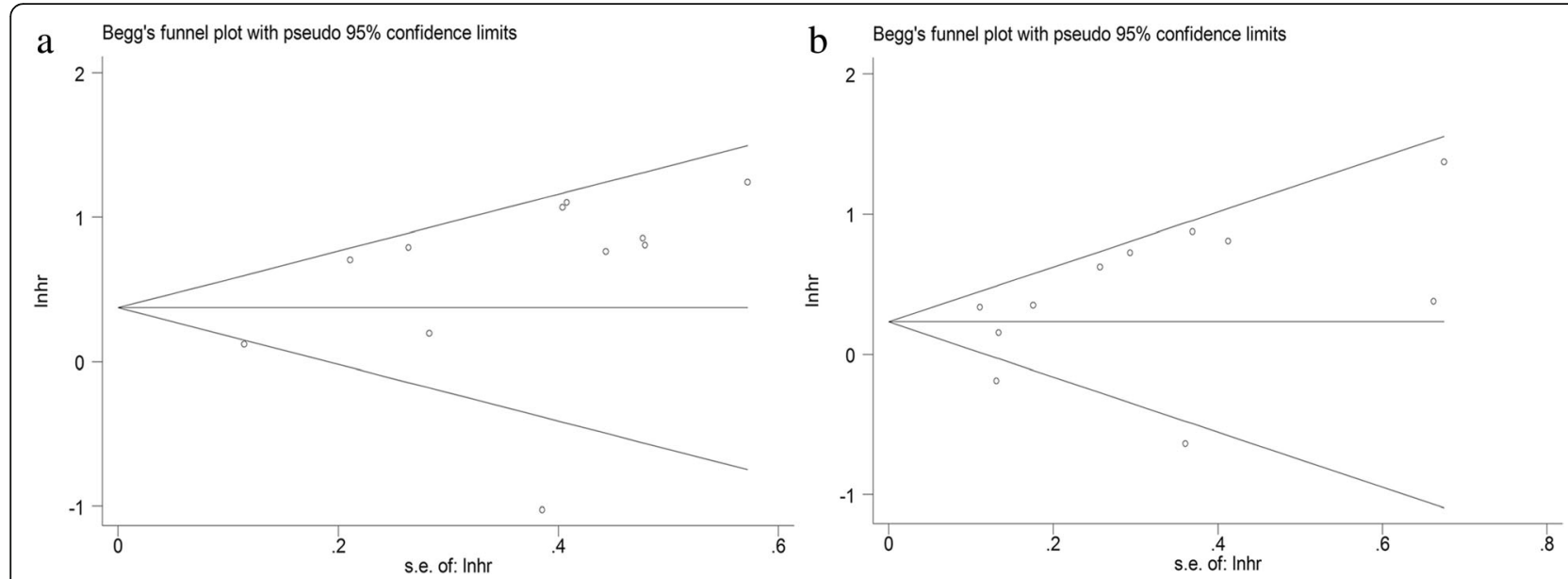

Fig. 7 Begg's funnel plots for evaluating publication bias in the meta-analysis for prognosis. a. Funnel plot of the studies for DFS. b. Funnel plot of the studies for OS

components including nucleus, nucleoplasm and nucleolus, which have been demonstrated to be associated with the proliferation and invasion of CRC [42]. For MF, the targets of miR-106a and miR-106b were mainly linked with the binding function and enzyme activity, which has also been proved to be involved in the development and classification of CRC [43, 44].

What's more, the KEGG pathway enrichment analysis revealed that some important pathways associated with miR-106a and miR-106b might take part in the pathogenesis of CRC according to literature exploration. For example, the colorectal cancer pathway directly proved that miR-106 indeed participated in the occurrence and development of CRC. FoxO signaling pathway, which is the central regulator of cellular homeostasis and tumor suppressors in human cancers, plays a central role in diverse physiological processes from development, cell signaling, and tumorigenesis to cell metabolism [45]. With regard to the MAPK signaling pathway, its imbalance in expression is associated with various cellular activities involved in cancer progression, including proliferation, apoptosis and immune escape [46]. Cell cycle, perhaps the most important pathway with a high correlation with colorectal carcinogenesis, plays its role through regulating cell growth, differentiation, apoptosis, cancer development and metastasis [47]. There is mounting evidence to indicate that activation of this pathway contributes to the pathogenesis, progression, and oncogenic behavior of human CRC [48]. About the focal adhesion pathway, accumulating new evidence supports the concept that it plays important roles in the invasion and metastasis of a variety of tumors and is correlated with the medicine resistance of certain tumors [49]. RNA degradation is a highly crucial process in the regulation of gene expression. The abnormal activation of this pathway may contribute to the physiological alterations towards carcinogenesis [50]. The functional enrichment results indicated the preliminary roles of miR-106 family in the occurrence and development of CRC, which should be evaluated and validated by further mechanistic studies.

There is still a long way for the application miR-106 into clinical practice. Although qRT-PCR was the most common method for detecting miR-106 expression, in situ hybridization (ISH) was also used in some studies. Both qRT-PCR and ISH may provide a reliable evidence for cancer detection and have their own disadvantages as well. However, heterogeneity may result from different laboratories using different methods to quantify miR-106. There is thus a great need for further studies to reach agreement on the procedure used for normalization. Various sample sources (tissue, plasma, serum, feces) have presented the potential for detecting miR-106. We supposed that tissue miR-106 could be applied for predicting the survival outcome and circulating miR-106 may act as an auxiliary marker, monitoring the level of miR-106 in the body. For clinical purpose, it requires more studies and analyses to investigate the diagnostic value of miR-106 in specific specimen for detecting CRC.

Several limitations of our study should be considered before interpreting the results. Firstly, the lack of access to the original data from the studies may hinder the integrated investigation of the associations between miR106 expression and the diagnosis and prognosis of CRC, which is the main problem. Secondly, there were only six studies included in the evaluation of diagnosis value of miR-106 family, so the statistical power of our study may be constrained. Thirdly, no study was conducted in Africa, which may also restrict the research extent.

Despite these limitations, our study had several important strengths. To begin with, a relatively thorough 
Table 4 GO enrichment analysis results for miR-106a

\begin{tabular}{|c|c|c|}
\hline \multicolumn{3}{|l|}{$\mathrm{BP}$} \\
\hline GO terms & Genes & $\boldsymbol{P}$-value \\
\hline Peptidyl-serine phosphorylation & 24 & 7.10E-07 \\
\hline Cell cycle arrest & 16 & 2.07E-06 \\
\hline Regulation of mitotic cell cycle & 10 & $1.51 \mathrm{E}-05$ \\
\hline $\begin{array}{l}\text { Negative regulation of TGF- } \beta \text { receptor } \\
\text { signaling pathway }\end{array}$ & 12 & 1.26E-04 \\
\hline Cellular response to amino acid stimulus & 11 & $1.50 \mathrm{E}-04$ \\
\hline $\begin{array}{l}\text { Protein ubiquitination involved in ubiquitin- } \\
\text { dependent protein catabolic process }\end{array}$ & 20 & $1.61 \mathrm{E}-04$ \\
\hline Protein autophosphorylation & 19 & 2.91E-04 \\
\hline $\begin{array}{l}\text { Transforming growth factor beta } \\
\text { receptor signaling pathway }\end{array}$ & 12 & 7.78E-04 \\
\hline $\begin{array}{l}\text { Plus-end-directed vesicle transport } \\
\text { along microtubule }\end{array}$ & 4 & $1.37 \mathrm{E}-03$ \\
\hline Mitochondrial genome maintenance & 5 & $1.43 \mathrm{E}-03$ \\
\hline \multicolumn{3}{|l|}{ CC } \\
\hline GO terms & Genes & $P$-value \\
\hline Cytoplasm & 269 & $1.64 \mathrm{E}-14$ \\
\hline Nucleus & 255 & $2.89 \mathrm{E}-10$ \\
\hline Nucleoplasm & 136 & 1.40E-07 \\
\hline Membrane & 96 & $6.43 \mathrm{E}-07$ \\
\hline Focal adhesion & 41 & $3.48 \mathrm{E}-05$ \\
\hline Nucleolus & 65 & $5.42 \mathrm{E}-05$ \\
\hline CCR4-NOT complex & 7 & $6.55 \mathrm{E}-05$ \\
\hline Centrosome & 39 & 2.15E-04 \\
\hline Transcription factor complex & 25 & 2.26E-04 \\
\hline Cytoskeleton & 17 & 2.79E-04 \\
\hline \multicolumn{3}{|l|}{ MF } \\
\hline GO terms & Genes & $P$-value \\
\hline ATP binding & 124 & 1.47E-06 \\
\hline Protein serine/threonine kinase activity & 33 & 4.69E-05 \\
\hline Poly(A) RNA binding & 90 & 2.25E-04 \\
\hline Ubiquitin-protein transferase activity & 23 & 4.79E-04 \\
\hline RNA binding & 33 & $6.95 \mathrm{E}-04$ \\
\hline $\begin{array}{l}\text { Thiol-dependent ubiquitin-specific } \\
\text { protease activity }\end{array}$ & 14 & 7.26E-04 \\
\hline Znc ion binding & 93 & $1.11 \mathrm{E}-03$ \\
\hline 1-phosphatidylinositol binding & 6 & $1.30 \mathrm{E}-03$ \\
\hline $\begin{array}{l}\text { Receptor signaling protein serine/ } \\
\text { threonine kinase activity }\end{array}$ & 11 & $2.78 \mathrm{E}-03$ \\
\hline DNA binding & 59 & $4.38 \mathrm{E}-03$ \\
\hline
\end{tabular}

GO gene ontology, $B P$ biological process, $C C$ cellular component, $M F$ molecular function
Table 5 GO enrichment analysis results for miR-106b

\begin{tabular}{|c|c|c|}
\hline \multicolumn{3}{|l|}{$\mathrm{BP}$} \\
\hline GO terms & Genes & $\boldsymbol{P}$-value \\
\hline Transcription, DNA-templated & 309 & 4.29E-12 \\
\hline Protein ubiquitination & 82 & 1.53E-10 \\
\hline $\begin{array}{l}\text { Negative regulation of transcription } \\
\text { from RNA polymerase II promoter }\end{array}$ & 135 & $3.84 \mathrm{E}-10$ \\
\hline Viral process & 66 & 4.52E-08 \\
\hline Protein polyubiquitination & 47 & $5.79 \mathrm{E}-08$ \\
\hline $\begin{array}{l}\text { Protein ubiquitination involved in ubiquitin- } \\
\text { dependent protein catabolic process }\end{array}$ & 41 & 1.15E-07 \\
\hline Cellular response to DNA damage stimulus & 49 & 4.09E-07 \\
\hline Cell-cell adhesion & 59 & 4.12E-07 \\
\hline $\begin{array}{l}\text { Positive regulation of transcription, DNA- } \\
\text { templated }\end{array}$ & 94 & 7.99E-07 \\
\hline $\begin{array}{l}\text { Positive regulation of transcription from } \\
\text { RNA polymerase II promoter }\end{array}$ & 157 & $8.43 \mathrm{E}-07$ \\
\hline
\end{tabular}

\section{CC}

GO terms

Genes $\quad P$-value

Nucleoplasm

509 4.53E-41

Nucleus

$817 \quad 4.14 \mathrm{E}-36$

Cytoplasm

8.37E-28

Cytosol

$2.68 \mathrm{E}-22$

Membrane

$2.06 \mathrm{E}-13$

Nucleolus

Cell-cell adherens junction

6.39E-11

Intracellular membrane-bounded

$8.52 \mathrm{E}-09$

organelle

Midbody

Perinuclear region of cytoplasm

762

153

70

1.50E-07

MF

3.50E-07

103

3.83E-06

\section{GO terms}

Protein binding

Poly(A) RNA binding

Ubiquitin-protein transferase activity

Ubiquitin protein ligase binding

Ubiquitin protein ligase activity

Cadherin binding involved in cell-cell adhesion

Transcription factor activity, sequence-

$\begin{array}{ll}\text { Genes } & \boldsymbol{P} \text {-value } \\ 1251 & 6.93 \mathrm{E}-44 \\ 211 & 5.55 \mathrm{E}-15 \\ 81 & 5.55 \mathrm{E}-12 \\ 70 & 2.73 \mathrm{E}-10 \\ 52 & 5.74 \mathrm{E}-10 \\ 67 & 7.22 \mathrm{E}-09 \\ & \\ 155 & 1.02 \mathrm{E}-06 \\ & \\ 246 & 1.35 \mathrm{E}-06 \\ 221 & 3.40 \mathrm{E}-06 \\ 72 & 4.18 \mathrm{E}-06\end{array}$

GO gene ontology, BP biological process, CC cellular component, MF molecular function 
Table 6 KEGG pathway analysis for miR-106 family

\begin{tabular}{lll}
\hline A, miR-106a & Genes & $\boldsymbol{P}$-value \\
\hline Pathway & 28 & $3.62 \mathrm{E}-08$ \\
\hline FoxO signaling pathway & 35 & $3.54 \mathrm{E}-07$ \\
Focal adhesion & 26 & $8.70 \mathrm{E}-07$ \\
Hepatitis C & 15 & $5.81 \mathrm{E}-05$ \\
Colorectal cancer & 32 & $1.44 \mathrm{E}-04$ \\
Endocytosis & 17 & $1.44 \mathrm{E}-04$ \\
Prostate cancer & 45 & $1.64 \mathrm{E}-04$ \\
Pathways in cancer & 15 & $1.83 \mathrm{E}-04$ \\
Adherens junction & 14 & $2.75 \mathrm{E}-04$ \\
Pancreatic cancer & 32 & $4.58 \mathrm{E}-04$ \\
MAPK signaling pathway & & \\
B, miR-106b & $\mathbf{G e n e s}$ & $\boldsymbol{P}$-value \\
Pathway & 33 & $2.14 \mathrm{E}-06$ \\
Cell cycle & 39 & $8.97 \mathrm{E}-06$ \\
Protein processing in endoplasmic reticulum & 33 & $1.25 \mathrm{E}-05$ \\
FoxO signaling pathway & $3.17 \mathrm{E}-05$ \\
Pathways in cancer & 70 & $\mathbf{3}$ \\
Prostate cancer & 24 & $4.63 \mathrm{E}-05$ \\
Hepatitis C & 31 & $7.36 \mathrm{E}-05$ \\
RNA degradation & 21 & $1.57 \mathrm{E}-04$ \\
Hepatitis B & 32 & $1.61 \mathrm{E}-04$ \\
Chronic myeloid leukemia & 20 & $1.82 \mathrm{E}-04$ \\
Endocytosis & 46 & $1.87 \mathrm{E}-04$ \\
\hline & & \\
& & \\
& &
\end{tabular}

systematic search was carried out, and the biomarker roles of miR-106 family in the diagnosis and prognosis of CRC were independently assessed and validated. Then, we not only quantitatively demonstrated that miR-106 family may have potential to serve as a promising and non-invasive biomarker for CRC, but qualitatively indicated the underlying roles of miR-106 family in the occurrence and development of CRC. Besides, our study also provided some interesting information, which deserved further investigation.

\section{Conclusions}

In summary, our integrated analysis identified miR-106 family to be highly involved in the initiation and progression of CRC and could be potential and promising biomarker for the preliminary screening and survival prediction of CRC. The results would be helpful for promoting miR-106 family into the clinical application as biomarkers for the diagnosis and prognosis of CRC. However, more large-scale prospective studies are required to clarify the diagnostic efficiency and prognostic value of miR-106 in CRC. Moreover, the specific mechanisms of miR-106 family in tumorigenesis of CRC need to be further explored by biological experiments.

\section{Abbreviations}

CRC: Colorectal cancer; AUC: Area under the curve; TP: True positive; FP: False positive; FN: False negative; TN: True negative; PLR: Positive likelihood ratios; NLR: Negative likelihood ratios; DOR: Diagnostic odds ratio; Cl: Confidence interval; SROC: Summary receiver operator characteristic; QUADAS-2: Quality Assessment of Diagnostic Accuracy Studies 2; GO: Gene ontology; KEGG: Kyoto Encyclopedia of Genes and Genomes; DAVID: Database for Annotation, Visualization, and Integrated Discovery; BP: Biological process; CC: Cellular component; MF: Molecular function

\section{Acknowledgements}

Not applicable.

Ethics approval and consent to participate.

Not applicable.

Declarations

Not applicable.

\section{Authors' contributions}

QP and YS collected and processed data, and drafted the manuscript. PZ took part in the statistical analysis, while $Y Z$ and $M C$ were responsible for the bioinformatics analysis. BX drafted and revised the manuscript. All authors read and approved the final manuscript.

\section{Funding}

This work was supported by Jiangsu Commission of Health medical research project (H2018115), Advance Research Program for Young and Middle-aged Backbone of Suzhou Science \& Technology Town Hospital (2019Y04), Suzhou Introduction Project of Clinical Medical Expert Group (SZYJTD201804),

Suzhou Science and Technology Development Project (SYS2019059), Jiangsu Medical Innovation Team (CXDT-37), and the Second Affiliated Hospital of Soochow University Preponderant Clinic Discipline Group Project funding (XKQ2015005). Funding bodies did not have any role in the design of the study, data collection, analysis, interpretation of data or writing the manuscript.

\section{Availability of data and materials}

Data is available from the corresponding author upon reasonable request.

\section{Consent for publication}

Not Applicable.

\section{Competing interests}

The authors declare they have no competing interest.

\section{Author details}

'Department of Radiotherapy \& Oncology, The Second Affiliated Hospital of Soochow University, Suzhou, China. ${ }^{2}$ Institute of Radiotherapy \& Oncology, Soochow University, Suzhou, China. ${ }^{3}$ Department of Radiation Oncology, The Affiliated Suzhou Science \& Technology Town Hospital of Nanjing Medical University, Suzhou, China. ${ }^{4}$ Dept. of General Surgery, The Second Affiliated Hospital of Soochow University, San Xiang Road No. 1055, Suzhou 215004, Jiangsu, China.

Received: 28 November 2019 Accepted: 14 April 2020

Published online: 03 June 2020

\section{References}

1. Siegel RL, Miller KD, Jemal A. Cancer statistics, 2019. CA Cancer J Clin. 2019; 69(1):7-34.

2. McLeod M, Kvizhinadze G, Boyd M, et al. Colorectal Cancer screening: how health gains and cost-effectiveness vary by ethnic group, the impact on health inequalities, and the optimal age range to screen. Cancer Epidemiol Biomark Prev. 2017;26(9):1391-400.

3. Fillon M. Study aims to improve colorectal cancer screening rates. CA Cancer J Clin. 2019;69(3):161-3.

4. Treiber T, Treiber N, Meister G. Regulation of microRNA biogenesis and its crosstalk with other cellular pathways. Nat Rev Mol Cell Biol. 2019;20(1):5-20. 
5. Rupaimoole R, Slack FJ. MicroRNA therapeutics: towards a new era for the management of cancer and other diseases. Nat Rev Drug Discov. 2017;16(3): 203-22.

6. Peng Q, Shen Y, Lin K, Zou L, Shen Y, Zhu Y. Comprehensive and integrative analysis identifies microRNA-106 as a novel non-invasive biomarker for detection of gastric cancer. J Transl Med. 2018;16(1):127.

7. Zhang B, Xu CW, Shao Y, et al. Evaluation and identification of microRNA106 in the diagnosis of cancer: a meta-analysis. Int J Clin Exp Med. 2014; 7(10):3746-56

8. Hao H, Liu L, Zhang D, et al. Diagnostic and prognostic value of miR-106a in colorectal cancer. Oncotarget. 2017;8(3):5038-47.

9. Whiting PF, Rutjes AW, Westwood ME, et al. QUADAS-2: a revised tool for the quality assessment of diagnostic accuracy studies. Ann Intern Med. 2011;155(8):529-36.

10. Stang A. Critical evaluation of the Newcastle-Ottawa scale for the assessment of the quality of nonrandomized studies in meta-analyses. Eur J Epidemiol. 2010;25(9):603-5.

11. Reitsma JB, Glas AS, Rutjes AW, Scholten RJ, Bossuyt PM, Zwinderman AH. Bivariate analysis of sensitivity and specificity produces informative summary measures in diagnostic reviews. J Clin Epidemiol. 2005;58(10):982-90.

12. Jones CM, Athanasiou T. Summary receiver operating characteristic curve analysis techniques in the evaluation of diagnostic tests. Ann Thorac Surg. 2005;79(1):16-20.

13. Higgins JP, Thompson SG, Deeks JJ, Altman DG. Measuring inconsistency in meta-analyses. BMJ. 2003;327(7414):557-60.

14. Mueller M, D'Addario M, Egger M, et al. Methods to systematically review and meta-analyse observational studies: a systematic scoping review of recommendations. BMC Med Res Methodol. 2018;18(1):44.

15. Lin L, Chu H. Quantifying publication bias in meta-analysis. Biometrics. 2018; 74(3):785-94.

16. Karagkouni D, Paraskevopoulou MD, Chatzopoulos S, et al. DIANA-TarBase v8: a decade-long collection of experimentally supported miRNA-gene interactions. Nucleic Acids Res. 2018;46(D1):D239-45.

17. The Gene Ontology C. The gene ontology resource: 20 years and still GOing strong. Nucleic Acids Res. 2019;47(D1):D330-8.

18. Kanehisa M, Furumichi M, Tanabe M, Sato Y, Morishima K. KEGG: new perspectives on genomes, pathways, diseases and drugs. Nucleic Acids Res. 2017:45(D1):D353-61.

19. Dennis G, Jr., Sherman BT, Hosack DA, et al. DAVID: database for annotation, visualization, and integrated discovery. Genome Biol 2003;4(5):P3.

20. Koga Y, Yamazaki N, Yamamoto Y, et al. Fecal miR-106a is a useful marker for colorectal cancer patients with false-negative results in immunochemical fecal occult blood test. Cancer Epidemiol Biomark Prev. 2013;22(10):1844-52.

21. Luo X, Stock C, Burwinkel B, Brenner H. Identification and evaluation of plasma microRNAs for early detection of colorectal cancer. PLoS One. 2013; 8(5):e62880.

22. Chen WY, Zhao XJ, Yu ZF, et al. The potential of plasma miRNAs for diagnosis and risk estimation of colorectal cancer. Int J Clin Exp Pathol. 2015:8(6):7092-101.

23. Li J, Liu Y, Wang $C$, et al. Serum miRNA expression profile as a prognostic biomarker of stage II/II colorectal adenocarcinoma. Sci Rep. 2015;5:12921.

24. He $Y$, Wang $G$, Zhang $L$, et al. Biological effects and clinical characteristics of microRNA-106a in human colorectal cancer. Oncol Lett. 2017;14(1):830-6.

25. Diaz R, Silva J, Garcia JM, et al. Deregulated expression of miR-106a predicts survival in human colon cancer patients. Genes Chromosomes Cancer. 2008; 47(9):794-802.

26. Schetter AJ, Leung SY, Sohn JJ, et al. MicroRNA expression profiles associated with prognosis and therapeutic outcome in colon adenocarcinoma. JAMA. 2008;299(4):425-36.

27. Bovell LC, Shanmugam C, Putcha BD, et al. The prognostic value of microRNAs varies with patient race/ethnicity and stage of colorectal cancer. Clin Cancer Res. 2013;19(14):3955-65.

28. Zhang JX, Song W, Chen ZH, et al. Prognostic and predictive value of a microRNA signature in stage II colon cancer: a microRNA expression analysis. Lancet Oncol. 2013;14(13):1295-306.

29. Kjersem JB, Ikdahl T, Lingjaerde OC, Guren T, Tveit KM, Kure EH. Plasma microRNAs predicting clinical outcome in metastatic colorectal cancer patients receiving first-line oxaliplatin-based treatment. Mol Oncol. 2014;8(1):59-67.

30. Ak S, Tunca B, Tezcan $G$, et al. MicroRNA expression patterns of tumors in early-onset colorectal cancer patients. J Surg Res. 2014;191(1):113-22.
31. Bullock MD, Pickard K, Mitter R, et al. Stratifying risk of recurrence in stage ॥ colorectal cancer using deregulated stromal and epithelial microRNAs. Oncotarget. 2015;6(9):7262-79.

32. Wang $Y X$, Lang F, Liu YX, Yang CQ, Gao HJ. In situ hybridization analysis of the expression of miR-106b in colonic cancer. Int J Clin Exp Pathol. 2015;8(1):786-92.

33. Yue B, Sun B, Liu C, et al. Long non-coding RNA Fer-1-like protein 4 suppresses oncogenesis and exhibits prognostic value by associating with miR-106a-5p in colon cancer. Cancer Sci. 2015;106(10):1323-32.

34. Zhang GJ, Li JS, Zhou H, Xiao HX, Li Y, Zhou T. MicroRNA-106b promotes colorectal cancer cell migration and invasion by directly targeting DLC1. J Exp Clin Cancer Res. 2015;34:73.

35. Caritg O, Navarro A, Moreno I, et al. Identifying high-risk stage II Colon Cancer patients: a three-MicroRNA-based score as a prognostic biomarker. Clin Colorectal Cancer. 2016;15(4):e175-82.

36. Hao H, Xia G, Wang C, Zhong F, Liu L, Zhang D. miR-106a suppresses tumor cells death in colorectal cancer through targeting ATG7. Med Mol Morphol. 2017;50(2):76-85.

37. Kuriyama S, Hamaya Y, Yamada T, Sugimoto M, Osawa S, Sugimoto K, Mlyajima H, Kanaoka S. Tu1191 Fecal MicroRNA Assays as a Marker for Colorectal Cancer Screening. Gastroenterology 2012;142(5):S-770.

38. Ashton TM, McKenna WG, Kunz-Schughart LA, Higgins GS. Oxidative phosphorylation as an emerging target in Cancer therapy. Clin Cancer Res. 2018;24(11):2482-90

39. Soleimani A, Khazaei M, Ferns GA, Ryzhikov M, Avan A, Hassanian SM. Role of TGF-beta signaling regulatory microRNAs in the pathogenesis of colorectal cancer. J Cell Physiol. 2019. Jan 26. doi: 10.1002/jcp.28169.

40. Mitra P. Transcription regulation of MYB: a potential and novel therapeutic target in cancer. Ann Transl Med. 2018;6(22):443.

41. Ma X, Dang Y, Shao X, Chen X, Wu F, Li Y. Ubiquitination and Long Noncoding RNAs Regulate Actin Cytoskeleton Regulators in Cancer Progression. Int J Mol Sci. 2019;20(12)

42. Campbell SL, Wellen KE. Metabolic signaling to the nucleus in Cancer. Mol Cell. 2018;71(3):398-408

43. Ke J, Wu R, Chen Y, Abba ML. Inhibitor of DNA binding proteins: implications in human cancer progression and metastasis. Am J Transl Res. 2018;10(12):3887-910.

44. Short SP, Thompson JJ, Bilotta AJ, et al. Serine threonine kinase 17A maintains the epithelial state in colorectal Cancer cells. Mol Cancer Res. 2019;17(4):882-94

45. Ma J, Matkar S, He X, Hua X. FOXO family in regulating cancer and metabolism. Semin Cancer Biol. 2018;50:32-41.

46. Peluso I, Yarla NS, Ambra R, Pastore G, Perry G. MAPK signalling pathway in cancers: olive products as cancer preventive and therapeutic agents. Semin Cancer Biol. 2019:56:185-95.

47. Icard P, Fournel L, Wu Z, Alifano M, Lincet H. Interconnection between metabolism and cell cycle in Cancer. Trends Biochem Sci. 2019:44(6):490-501.

48. Zheng K, He Z, Kitazato K, Wang Y. Selective autophagy regulates cell cycle in Cancer therapy. Theranostics. 2019;9(1):104-25.

49. Zhou J, Yi Q, Tang L. The roles of nuclear focal adhesion kinase (FAK) on Cancer: a focused review. J Exp Clin Cancer Res. 2019:38(1):250.

50. Baudrimont A, Jaquet V, Wallerich S, Voegeli S, Becskei A. Contribution of RNA degradation to intrinsic and extrinsic noise in gene expression. Cell Rep. 2019;26(13):3752-61 e3755.

\section{Publisher's Note}

Springer Nature remains neutral with regard to jurisdictional claims in published maps and institutional affiliations.

\section{Ready to submit your research? Choose BMC and benefit from:}

- fast, convenient online submission

- thorough peer review by experienced researchers in your field

- rapid publication on acceptance

- support for research data, including large and complex data types

- gold Open Access which fosters wider collaboration and increased citations

- maximum visibility for your research: over $100 \mathrm{M}$ website views per year

At $\mathrm{BMC}$, research is always in progress.

Learn more biomedcentral.com/submission 